\title{
A mixed endocrine adrenal tumour causing steatorrhoea
}

\author{
P THESLEFF, C BENONI, H MÅTENSSON, Å NILSSON, F SUNDLER, \\ AND B ÅKESSON
}

From the Departments of Internal Medicine, Surgery, Histology and Clinical Chemistry, University of Lund, Lund, Sweden

SUmmary A 60 year old man developed steatorrhoea, weight loss, mild diabetes mellitus, labile hypertension and limb cramps. Raised plasma concentrations of catecholamines, particularly noradrenaline and a computed tomography-scan showing an adrenal tumour strongly suggested a pheochromocytoma. Adrenoreceptor blockade reversed the symptoms, decreased faecal fat, and increased duodenal trypsin to normal concentrations. After adrenalectomy the patient was asymptomatic and there was no steatorrhoea. The blood glucose concentrations became normal. Immunocytochemistry revealed the tumour cells to store large amounts of enkephalin and somatostatin reactive material and moderate amounts of immunoreactive $\beta$-endorphin and dynorphin.

The most common manifestations of pheochromocytoma are persistent or paroxysmal headache, sweating, palpitations, diabetes mellitus, weight loss, and hypermetabolism.'

Abdominal symptoms are usually not a major feature in pheochromocytoma, although nausea, vomiting, abdominal pain and, less frequently, diarrhoea and gastrointestinal bleeding, ${ }^{2}$ as well as obstipation, megacolon and paralytic ileus, ${ }^{3+}$ have been described. We know of no report in which malabsorption or significant steatorrhoea in patients with pheochromocytoma is described.

Somatostatin inhibits a variety of endocrine and exocrine functions. Patients with somatostatinoma often exhibit both steatorrhoea and mild diabetes mellitus." Although pheochromocytoma contain some somatostatin, opioid peptides and neuropeptide $\mathrm{Y}$, adrenal tumours producing large amounts of these peptides giving rise to specific symptoms have not been described. In this paper we describe a patient with diabetes mellitus and significant steatorrhoea who had an adrenal tumour producing large amounts of noradrenaline, somatostatin, and opioid peptides.

Address for correspondence: Dr Peter Thesleff. Department of Internal Medicine. University Hospital of L und. S-221 $85 \mathrm{I}$. und, Sweden.

Received for publication 26 February 1987

\section{Methods}

FAT ABSORPTION

The triolein breath test was done as described previously." The peak expiratory ${ }^{14} \mathrm{CO}_{2}$, expressed as per cent of given dose per hour, was used as a measure of fat absorption. Faecal fat was determined as described by van der Kamer et al. ${ }^{7}$ Urinary oxalate was determined by titration with permanganate, after giving $600 \mathrm{mg}$ sodium oxalate daily for three days.

Table 1 Details of peptide antisera used

\begin{tabular}{|c|c|c|c|}
\hline \multirow[b]{2}{*}{ Antigen } & \multirow[b]{2}{*}{ Codeno } & \multicolumn{2}{|c|}{ Working dilution } \\
\hline & & $\begin{array}{l}\text { Immuno- } \\
\text { fluorescence }\end{array}$ & $\begin{array}{l}\text { Immuno- } \\
\text { peroxidase }\end{array}$ \\
\hline Met-enkephalin* & 8107 & $1: 320$ & $1: 640$ \\
\hline Dynorphint & 8023 & $1: 40$ & $1: 160$ \\
\hline Rimorphin (dynorphin B) $\ddagger$ & 8329 & $1: 40$ & $1: 160$ \\
\hline$\beta$-endorphin & 7762 & $1: 80$ & $1: 640$ \\
\hline ACTH & 1 & $1: 80$ & $1: 320$ \\
\hline Calcitonin & 7714 & $1: 160$ & $1: 640$ \\
\hline
\end{tabular}

*no cross-reaction with $\beta$-endorphin or dynorphin; $†$ no crossreaction with Me- or Le-enkephalin of $\beta$-endorphin; $\ddagger$ no crossreaction with enkephalin. 
IMMUNOCYTOCHEMISTRY

Fresh tumour specimens were frozen in a mixture of propane and propylene, cooled to the temperature of liquid nitrogen, and freeze dried. They were then fixed by exposure to formaldehyde vapour for one hour at $80^{\circ} \mathrm{C}$ and embedded in paraffin in vacuo." Sections, mounted on albuminised slides were deparaffinised in xylene and hydrated. The sections were then processed for the immunocytochemical demonstration of various neurohormonal peptides known to occur in pheochromocytomas, as specified in Table 1, using the indirect immunofluorescence technique of Coons et al." Sections incubated with antiserum inactivated by the addition of antigen in excess $(10-100 \mathrm{~g}$ of pure natural or synthetic peptide per $\mathrm{ml}$ diluted antiserum) were used as controls. Details of the peptide antisera used are given in Table 1.

\section{Case report}

A 60 year old man without any family history of diabetes or other endocrine disorder was admitted to the hospital in 1979 complaining of anorexia, loose stools and weight loss of approximately $5 \mathrm{~kg}$ over a few months. Physical examination was normal. Serum amino transferases and $\gamma$-glutamyl transferase were slightly raised. He had a mild steatorrhoea (Fig. 1) and a slightly lowered xylose absorption. No definite diagnosis was made and after a few months the symptoms disappeared, and the laboratory examinations including the analysis of faecal fat became normal.

He remained well for another three years and was then readmitted complaining of increasing volumes of loose, light coloured stools, loss of weight and disabling limb cramps and episodes of vertigo and sweating. Physical examination was normal but the patient now not only had marked steatorrhoea, with faecal fat $130 \mathrm{mmol} / 24 \mathrm{~h}$ (normal $<17 \mathrm{mmol} / 24 \mathrm{~h}$ ) but also a non-ketotic diabetes mellitus. Blood glucose concentrations were constantly raised and showed no correlation to meals. Blood cell counts, serum concentrations of enzymes, serum isoamylase, serum electrolytes and urine analysis were all normal. Ultrasonography of the liver, gall bladder and pancreas was normal but revealed an enlarged adrenal gland on the right side. Blood pressure was now regularly recorded and at times rose to $250 / 10()$ $\mathrm{mm} \mathrm{Hg}$. A computed tomography scan revealed a tumour $(4-5 \mathrm{~cm})$ at the site of the right adrenal gland. Endoscopic retrograde cholangiopancreatography (Fig. 2) was normal. The concentration of trypsin in duodenal aspirate after a Lundh test meal was 75 $\mu \mathrm{kat} / \mathrm{l}$ (normal $>156 \mathrm{~kat} / \mathrm{l})$. Faecal fat was 124 $\mathrm{mmol} / 24 \mathrm{~h}$ and urinary oxalate was raised (Fig. 1) C-peptide $(0.46 \mathrm{nmol} / \mathrm{l}(() \cdot 25-() \cdot 75)$ and plasma insulin $4 \mathrm{mIU} / \mathrm{l} \quad(<25)$ were normal. Urine hydroxymethoxy-mandelate was $81-85 \mathrm{~mol} / 24 \mathrm{~h}$ (reference value $6-33 \mathrm{~mol} / 24 \mathrm{~h}$ ) and urine methoxycatechola-

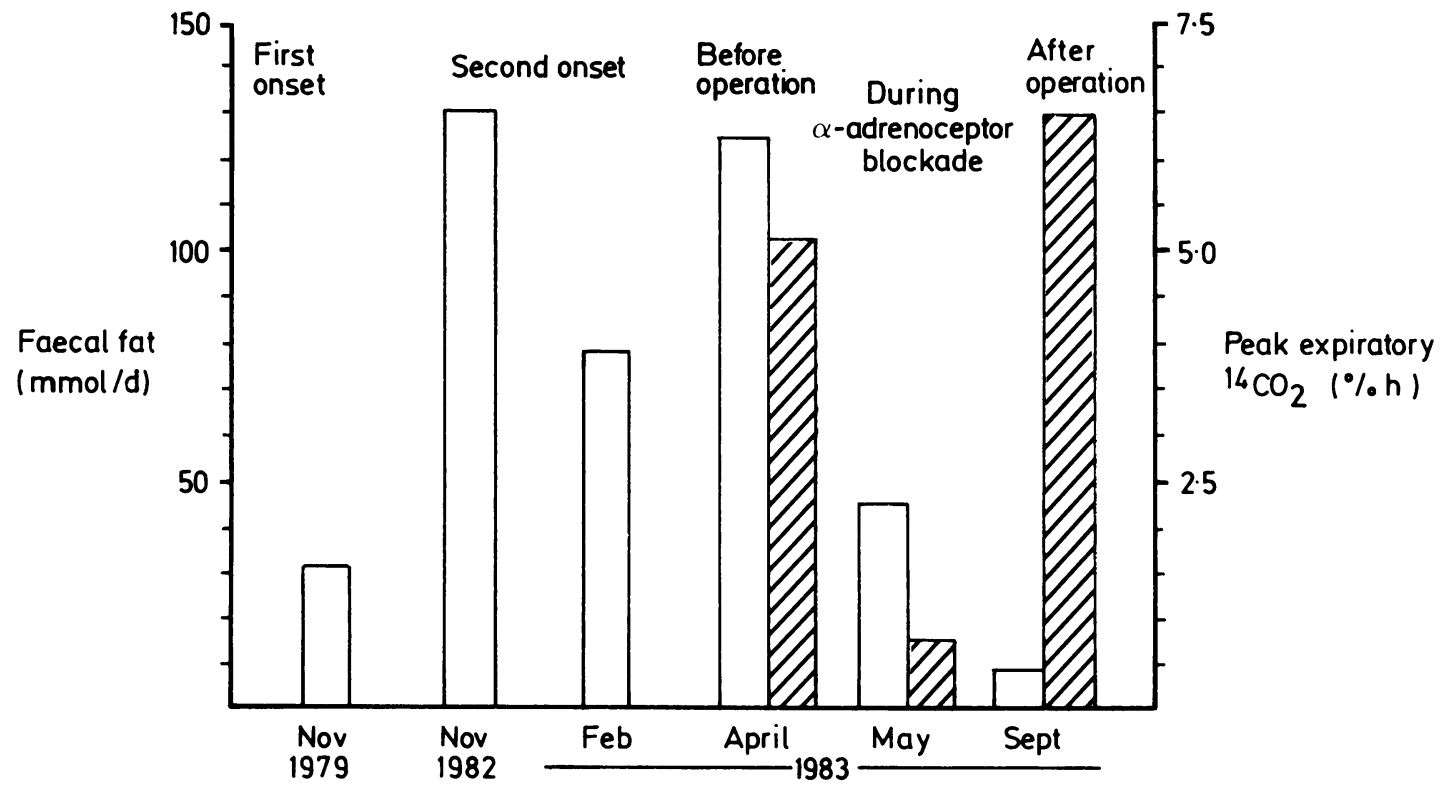

Fig. 1 Determinations of faecal fat ( $\square$ ), and ${ }^{1+}$ ('-triolein breath test (प) at various times. Note the high value of peak expiratory ${ }^{1+} \mathrm{C}_{2}$ before treatment. 

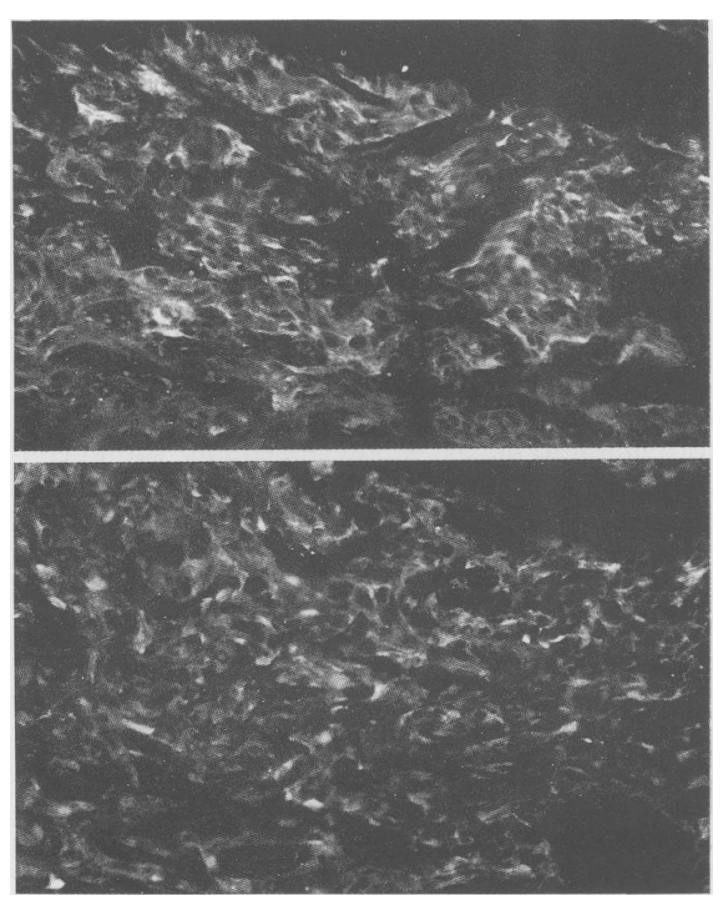

Fig. 2 Immunofluorescence micrographs of sections from the same tumour region using antisera against Metenkephalin (top) and somatostatin (below). Virtually all tumour cells are stained with each of the antisera implying coexistence of immunoreactive enkephalin and somatostatin in the cells of this tumour.

mines $24-53 \mathrm{~mol} / 24 \mathrm{~h}$ (reference value $0 \cdot 6-6 \cdot 0$ $\mathrm{mol} / 24 \mathrm{~h}$ ). During $\alpha$-adrenoceptor blockade with phenoxybenzamine (Dibenyline 20-60 mg per day for seven weeks) coeliac angiography was carried out. This showed a highly vascularised tumour. Selective venous sampling from the adrenal veins showed markedly raised concentrations of noradrenaline on the right side. Percutaneous transhepatic portography with selective sampling showed normal concentrations of serum pancreatic polypeptide. During the $\alpha$-adrenoceptor blockade there was a dramatic improvement: the diarrhoea and abdominal cramps disappeared. Faecal fat and urinary oxalate decreased markedly and trypsin in duodenal content was increased. The patient underwent adrenalectomy during $\alpha$-adrenoceptor blockade. At operation a $5 \times 5 \mathrm{~cm}$ encapsulated tumour was found in the right adrenal gland. This was removed without any technical problem. The left adrenal gland and the pancreas were normal. After the operation the patient has remained free of symptoms, and with no sign of diabetes mellitus. His blood pressure has been normal. Laboratory tests are summarised in Table 2.
Table 2 Summary of test results

\begin{tabular}{|c|c|c|c|}
\hline & $\begin{array}{l}\text { Before } \\
\text { treatment }\end{array}$ & $\begin{array}{l}\text { During } \alpha \text { - } \\
\text { adrenoreceptor } \\
\text { blockade }\end{array}$ & $\begin{array}{l}\text { After } \\
\text { adrenalectomy }\end{array}$ \\
\hline Faecal fat & 124 & 44 & 8 \\
\hline Duodenal trypsin & 75 & 175 & 249 \\
\hline C-triolein test & $5 \cdot 08$ & 0.74 & 6.46 \\
\hline Urine oxalate & $0 \cdot 35$ & $0 \cdot 18$ & $0 \cdot 19$ \\
\hline
\end{tabular}

Faecal fat $(<17 \mathrm{nmol} / 24 \mathrm{~h})$; trypsine in duodenal aspirate after Lundhs test meal (>156 ukat/1); $14 \mathrm{C}$-triolein test, maximal CO - $^{-}$ excretion after ${ }^{1+} \mathrm{C}$-triolein load (preliminary reference values $3 \cdot 3-7 \cdot 5 \% / \mathrm{h})$; urine oxalate after sodium oxalate load $(0 \cdot 24$ $\mathrm{mmol} / \mathrm{l})$.

\section{Results and Discussion}

The patient had a marked fat malabsorption with faecal excretion of between 130 and $77 \mathrm{mmol} / \mathrm{d}$ (Fig. 1). After $\alpha$-adrenergic blockade with phenoxybenzamine, faecal fat decreased to $44 \mathrm{mmol} / \mathrm{d}$ and after the operation it decreased further to normal values. The $14_{C}$ triolein breath test gave contrasting results. The peak expiratory ${ }^{14} \mathrm{CO}_{2}$ was normal initially but was low after $\alpha$-adrenoceptor blockade, when fat absorption was improved according to faecal fat measurements. After the operation the triolein breath test was normal. It is possible that the breath test overestimated the degree of fat absorption before the $\alpha$-adrenoreceptor blockade because of the stimulatory effect of the catecholamines on fatty acid oxidation.

Immunocytochemistry revealed that the vast majority of tumour cells displayed intense enkephalin and somatostatin immunoreactivity. Immunostaining of consecutive sections for the two peptides showed that both occurred in the same cells. In addition, single scattered or clustered cells displayed dynorphin of $\beta$-endorphin immunoreactivity. No immunostaining was obtained using ACTH or calcitonin antisera.

The tumour also seems to have produced multiple opioid peptides. The immunocytochemically identified opioids in the tumour comprised enkephalins, dynorphins and $\beta$-endorphin. There is recent evidence that all these peptides may occur not only in pheochromocytomas but also in the normal human adrenal medulla." The clinical significance of the production (and presumable secretion) of opioid peptides and somatostatin in pheochromocytomas is obscure.

The steatorrhoea decreased after $\alpha$-adrenoreceptor blockade indicating that the catecholamines contributed to the patients symptoms. The increase in the duodenal trypsin concentrations after the blockade suggests that suppression of exocrine 
pancreatic secretion by catecholamines'2 may be one factor contributing to the steatorrhoea. Faecal fat excretion was, however, not normal until after operation and reversible diabetes mellitus and steatorrhoea are also features of the somatostatinoma syndrome. ${ }^{5}$ Possible effects of the somatostatin and the opioid peptides present in the tumour have to be considered. The mechanisms by which this tumour induced steatorrhoea and reversible diabetes mellitus therefore remains unknown.

\section{References}

1 Herman $\mathrm{H}$, Mornex R. Human tumours secreting catecholamines. Oxford: Pergamon Press, 1964.

2 Roach PS. Gastrointestinal bleeding in pheochromocytoma and following the administration of norepinephrine (arterenol). Arch Intern Med 1959; 104: 175-7.

3 Gifford RW, Kvale WF, Maher FT, et al. Clinical features, diagnosis and treatment of pheochromocytoma: a review of 76 cases. Mayo Clin Proc 1964; 39: 281-302.

4 Brown RB, Borowsky M. Further observation on intestinal lesions associated with pheochromocytoma. Ann Surg 1960; 151: 683-92.

5 Krejs GJ, Orci L, Conlon JM, et al. Somatostatinoma syndrome: biochemical, morphologic and clinical features. $N$ Engl J Med 1979; 301: 285-92.

6 Åkesson B, Florén $\mathrm{CH}$. Use of the triolein breath test for the demonstration of fat malabsorption in coeliac disease. Scand J Gastroenterol 1984; 19: 307-14.

7 van der Kamer JH, ten Bokkel Huinink H. Weyers HA. Rapid method for the determination of fat in feces. J Biol Chem 1949; 177: 347-55.

8 Brante E, Colleen S. Oxalic acid. Scand J Gastroenterol 1979; 14: suppl 52: 208-13.

9 Björklund A. Falck B. An improvement of the histochemical fluorescence method for monoamines. Observations on varying extractability of fluorophores in different nerve fibres. J Histochem Cytochem 1968; 16: 717-20.

10 Coons AH, Leduc EH, Connolly JM. Studies on antibody production. I. A method for the histochemical demonstration of specific antibody and its application to a study of the hyperimmune rabbit. $J$ Exp Med 1955 102: 49-60.

11 Lundberg JM, Hamberger B, Scheullzenberg M, et al. Enkephalin- and somatostatin-like immunoreactives in human adrenal medulla and pheochromocytoma. Proc Natl Acad Sci USA 1979; 76: 4079-83.

12 Eshaya Elisha E. Hutson D. Scatchard T. The direct inhibition of pancreatic electrolyte secretion by noradrenaline in the isolated perfused cat pancreas. J Physiol 1984; 351: 77-85. 